\title{
INFLUENCE OF ORIENTATION RELATIONSHIP BETWEEN FERRITE AND CEMENTITE IN PEARLITE ON STABILITY OF CEMENTITE PLATES
}

\section{INTRODUCTION}

\subsection{Pearlite spheroidization}

The most often met lamellar structure is a pearlite. Generally, the morphology of the pearlite is very complex. A variety of lamellar faults, e.g. kinks, holes, cementite of the fibres form and cementite particles of different shapes etc. are always occur [4].

It is well known, that the structure of pearlite is unstable and by annealing for a sufficient long time just below the eutectoid temperature it transforms from lamellar to spheroidal form. It is process of pearlite spheroidization [18].

For the analysis of pearlite spheroidization mechanism one can distinguish several partial structural processes:

- fragmentation,

- rounding off small plate segments into spherical particles particle coarsening,

- growth of ferrite grains.

There are many conceptions regarding a mechanism of spheroidization process: the Raylegh's perturbation theory $[10,11,13,28]$, the thermal groove theory $[2,6,12,15]$, the fault migration theory [10]. Unfortunately, the conceptions mentioned above do not explain fully the mechanism of spheroidization process, but in the area of possible interpretations they rather complete each other. Besides, none of the mentioned conceptions consider satisfactorily the factors like e.g. anisotropy of energy of interphase boundary ferrite/cementite.

The results of investigations of pearlite spheroidization kinetics do not also lead to unique conclusions. The values of process activation energy mentioned in a literature are characterized by a large discrepancy - from $90 \mathrm{~kJ} / \mathrm{mol}$ [14] up to $290 \mathrm{~kJ} / \mathrm{mol}$ [27]. An activation energy in range of $123-147 \mathrm{~kJ} / \mathrm{mol}$ was found for the spheroidization process

* D.Sc., Ph.D., Faculty of Metals Engineering and Industrial Computer Science, AGH University of Science and Technology, Krakow, Poland; czarski@agh.edu.pl 
by Skowronek and Czarski [23]. This range of values shows good agreement with the activation energy for iron and carbon diffusion along a ferrite/cementite interface, so a coupled interface diffusion is the rate-controlling process.

\subsection{Orientation relationships between cementite and ferrite}

It is stated that there are first of all two crystallographic orientations relationships (OR) between ferrite and cementite in pearlite as follows:

- the Bagaryatski OR [1]:

$$
\begin{aligned}
& {[100]_{\mathrm{Z}} \|[1 \overline{1} 1]_{\mathrm{F}},} \\
& {[010]_{\mathrm{Z}} \|[1 \overline{1} \overline{1}]_{\mathrm{F}},} \\
& (001)_{\mathrm{Z}} \|(11 \overline{2})_{\mathrm{F}} ;
\end{aligned}
$$

- the Pitsch OR [17];

$$
\begin{aligned}
& {[100]_{\mathrm{Z}} 2,6^{\circ} \text { from }[13 \overline{1}]_{\mathrm{F}},} \\
& {[010]_{\mathrm{Z}} 2,6^{\circ} \text { from }[113]_{\mathrm{F}},} \\
& (001)_{\mathrm{Z}} \|(5 \overline{2} \overline{1})_{\mathrm{F}},
\end{aligned}
$$

where subscripts $\mathrm{Z}$ and $\mathrm{F}$ refer to cementite and ferrite, respectively.

The Pitsch OR [17] occurs when pearlite nucleates on a "pure" boundary of austenite, while Bagaryacki OR [1] appears when pearlite nucleates on pre-eutectoid cementite $[5,7]$ (or on pre-eutectoid ferrite $[19,20]$ ). Simultaneously, the majority of results indicate that regardless a carbon content in steel and a degree of undercooling, dominating in a structure was the Pitsch OR (Pitsch [17] - carbon steels 0,25\% C, 0,7\% C, 1,25\% C, Stackleton and Kelly [22] - low-alloy steels from $0,52 \% \mathrm{C}$ to $0,96 \% \mathrm{C}$ and Hadfield steel, Lupton and Warrington [9] - carbon steel $0,8 \% \mathrm{C}$, Ohmori [16] - steel 0,19\% C, 0,0087\% B. The results of Sczastlivcev and Jakovleva [21] steel 1,12\% C, 4,25\% Mn, $0,28 \% \mathrm{Si}$ ) it would come that the domination in the structure of one orientation of two mentioned above depends on the degree of undercooling. OR:

There is also, but rarer mentioned the third orientation relationship i.e. the Isaichev

- the Isaichev OR [8]:

$$
\begin{aligned}
& (\overline{103})_{\mathrm{Z}} \|(110)_{\mathrm{F}}, \\
& {[010]_{\mathrm{Z}} \|[1 \overline{1} \overline{1}]_{\mathrm{F}},} \\
& {[311]_{\mathrm{Z}} 0,91^{\circ} \text { from }[1 \overline{1} 1]_{\mathrm{F}} .}
\end{aligned}
$$

The Isaichev OR [8] differs from the Bagaryatski OR [1] in rotation about $3,5^{\circ}$ around $[010]_{Z}$, but there is no unequivocal answer the question if it realizes instead of 
the Bagaryatski OR, whether these orientations occur in simultaneously [20, 25]. The presence of the Isaichev OR is stated very seldom, among others by Suchomlin [26] (steel $0,3 \% \mathrm{C}, 1,5 \% \mathrm{Mn}, 0,56 \% \mathrm{Si}$ ), where it appeared with the same frequency as the Pitsch OR apart from the temperature the pearlite transformation was being realized ( $873 \mathrm{~K}$ and $923 \mathrm{~K})$.

Besides three mentioned orientations, Zhang and Kelly [29, 30] have determined three orientations which are near to the Pitsch OR:

OR 1

$(\overline{1} 03)_{\mathrm{Z}} \mathrm{l}(\overline{1} 01)_{\mathrm{F}}$

$[010]_{\mathrm{z}} 8,5^{\circ}$ from $[131]_{\mathrm{F}}$

[311] z || [1 $\overline{1} 1]_{\mathrm{F}}$
OR 2

$$
(0 \overline{1} 1)_{\mathrm{Z}} \|(\overline{1} 01)_{\mathrm{F}}
$$$$
[311]_{\mathrm{z}}||[1 \overline{1} 1]_{\mathrm{F}}
$$

$[100]_{\mathrm{z}} 2,4^{\circ}$ from $[1 \overline{3} 1]_{\mathrm{F}}$
OR 3

$(210)_{\mathrm{Z}} \|(\overline{1} 01)_{\mathrm{F}}$

[001] z || [131] F

[1'21 ] z 5,95 from[101] $\mathrm{F}$

\section{EXPERIMENTAL PROCEDURE}

\subsection{Subject of experimental investigations}

The pearlite spheroidization process occurs not uniformly. Even, after long times of spheroidization annealing in microstructure still exists areas with lamellar structure and also single cementite plates. The reasons for the described behavior are not known.

In research of Skowronek and Czarski [24] it was stated the lamellar pearlite with smaller true interlamellar spacing tend to spheroidise more rapidly. The aim of the present work was to assess the influence of orientation relationships between ferrite and cementite in pearlite on a stability of cementite plates.

\subsection{Material and heat treatment}

A high purity Fe-C alloy was used in the experimental work. The chemical composition of the material is given in Table 1 .

Table1. Chemical composition of the steel under examination

\begin{tabular}{|c|c|c|c|c|c|c|c|c|c|c|c|c||}
\hline \hline Element & $\mathrm{C}$ & $\mathrm{Mn}$ & $\mathrm{Si}$ & $\mathrm{P}$ & $\mathrm{S}$ & $\mathrm{Cr}$ & $\mathrm{Ni}$ & $\mathrm{Cu}$ & $\mathrm{Al}_{\mathrm{c}}$ & $\mathrm{Al}_{\text {met }}$ & $\mathrm{N}$ & $\mathrm{Fe}$ \\
\hline$\%$ & 0.75 & 0.05 & 0.01 & 0.002 & 0.012 & 0.03 & 0.03 & 0.01 & 0.01 & 0.01 & 0.009 & rest \\
\hline
\end{tabular}

In order to produce a coarse lamellar pearlite, the material was subjected to the following heat treatment (Fig. 1):

- austenitizing $\left(900^{\circ} \mathrm{C} / 0,5 \mathrm{~h}\right)$ with subsequent transfer to lead bath at temperature $700^{\circ} \mathrm{C}$,

- isothermal holding in the bath $\left(700^{\circ} \mathrm{C} / 3 \mathrm{~h}\right)$. 


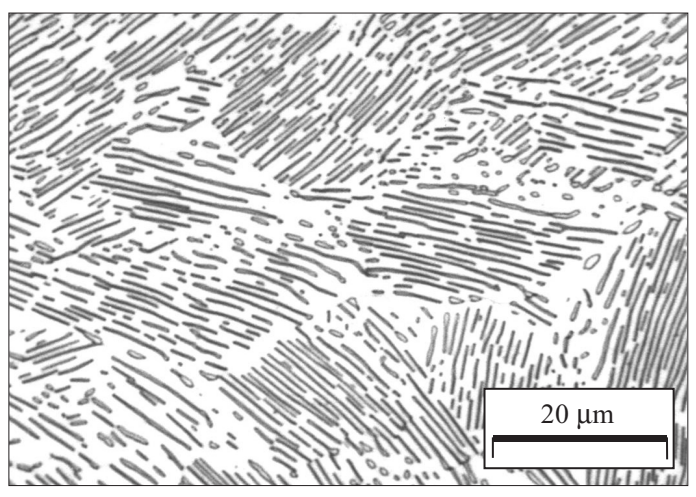

Fig. 1. Microstructure with coarse lamellar pearlite (etched in picral)

For spheroidization, the specimens were annealed at the temperature $700^{\circ} \mathrm{C}$ for the duration times ( $\mathrm{t}$ in hours): $\mathrm{t}=50, \mathrm{t}=100, \mathrm{t}=400$. The photomicrographs (Fig. 2) show the shape evolution of cementite plates during the spheroidization process.
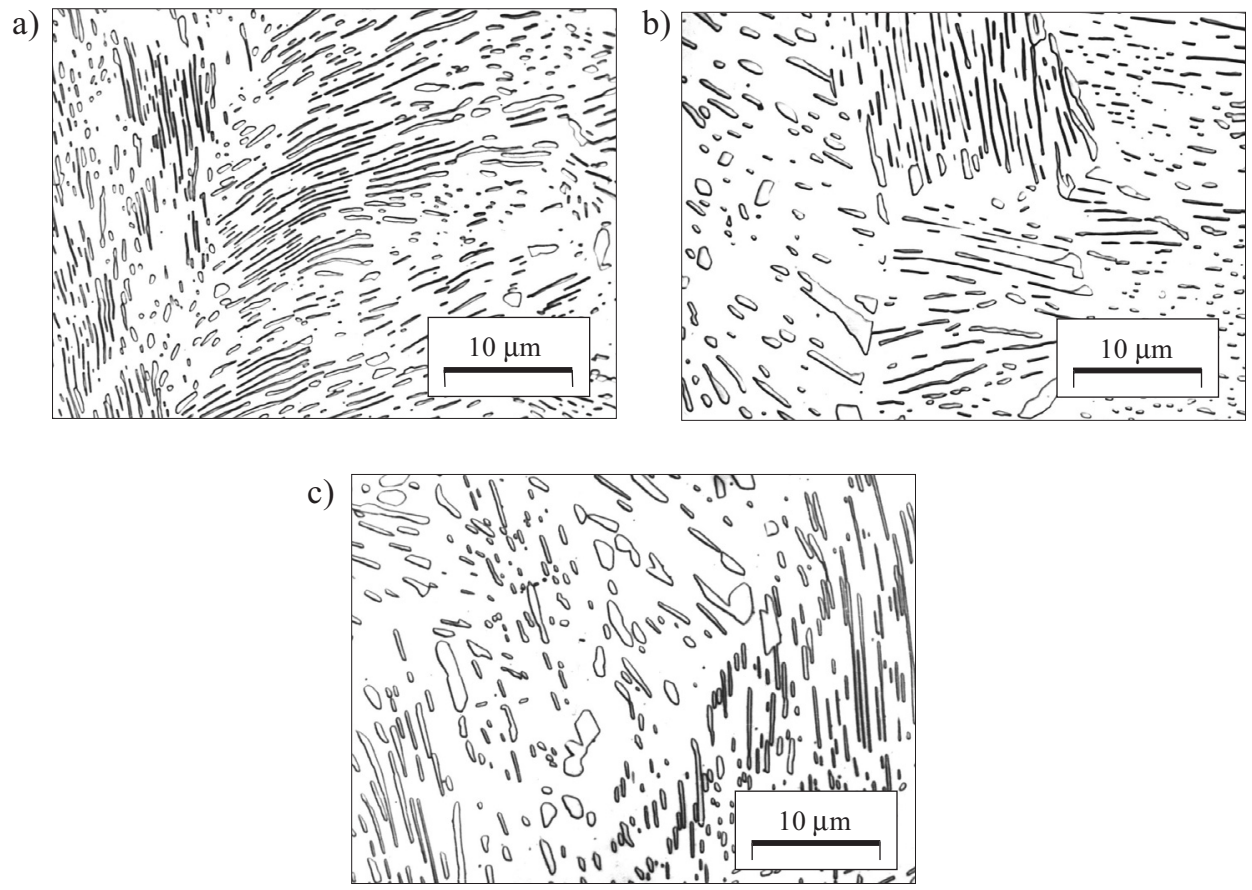

Fig. 2. Microstructures after different time of the spheroidization at $700^{\circ} \mathrm{C}$ : a) 50 hours; b) 100 hours; c) 400 hours (etched in picral) 
Thin foils were made by electropolishing using stream method in electrolyte consisted of perchloric acid (1 part) and glacial acetic acid (10 parts). Polishing was carried out at the voltage $50-55 \mathrm{~V}$ and temperature $12^{\circ} \mathrm{C}$. All thin foils were examined in a electron microscope JEOL 100C. With the aid of selective electron diffraction there was the determination of orientation relationship between ferrite and cementite made.

\subsection{Experimental results}

After eutectoid transformation (output state) the microstructure consists mainly of lamellar pearlite accompanied by only small fraction of speroidized cementite. The diffraction analysis showed the existence of the Pitsch OR (or close to it) (Fig. 3) or the Bagaryatski OR (Fig. 4).

a)

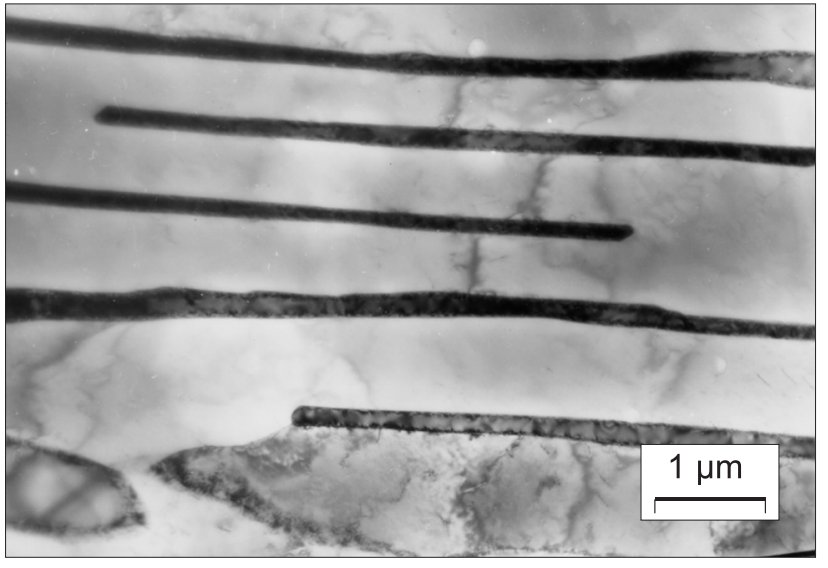

b)

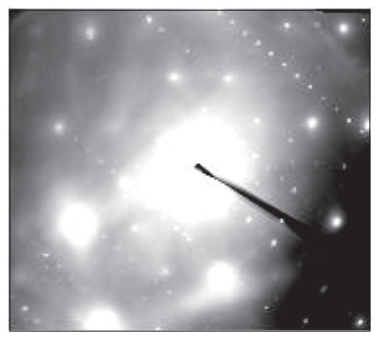

c)

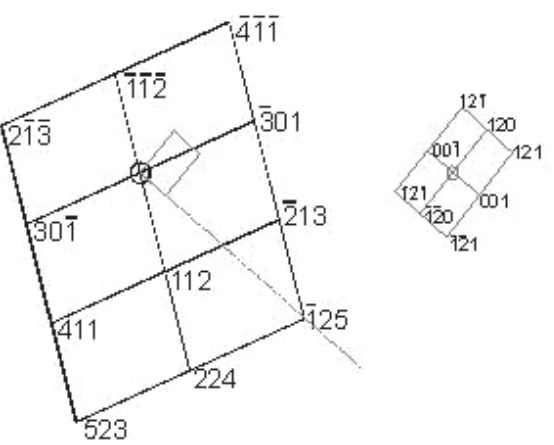

Fig. 3. Pearlite microstructure after eutectoid transformation (output state). Orientation near to the Pitch OR: a) bright-field image; b) diffraction pattern; c) diffraction pattern solution for ferrite, zone

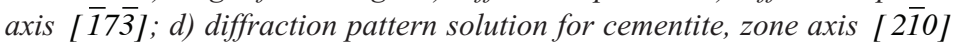


a)

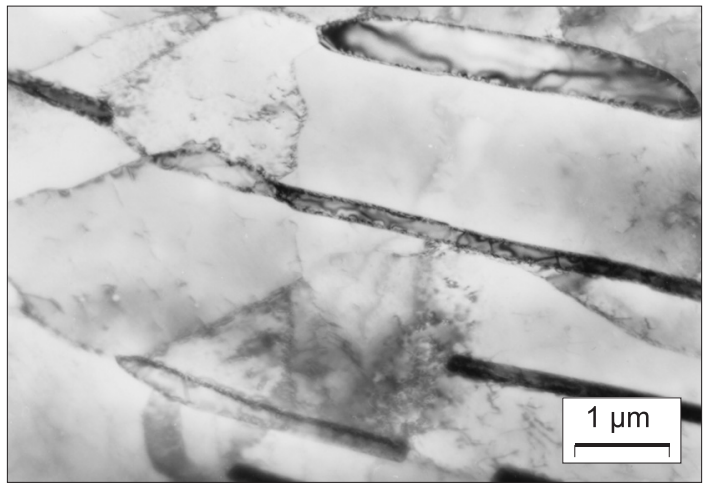

b)

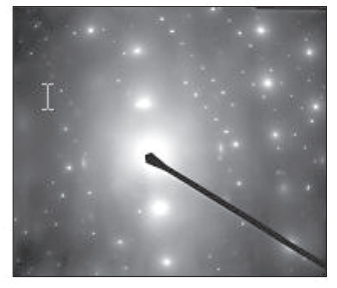

c) $\overline{3}$

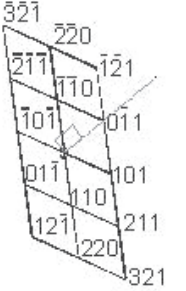

d)

Fig. 4. Pearlite microstructure after eutectoid transformation (output state). The Bagaryatski OR: a) bright-field image; b) diffraction pattern; c) diffraction pattern solution for ferrite, zone axis [1 $\overline{1} \overline{1}]$; d) diffraction pattern solution for cementite, zone axis [010]

a)

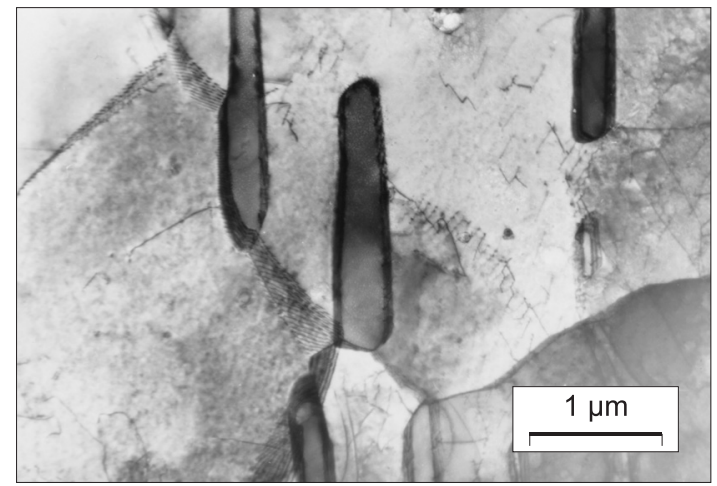

b)

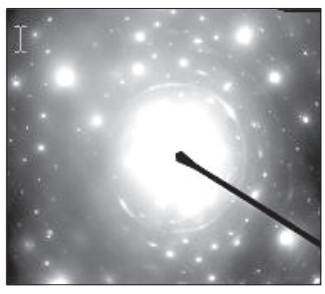

c)

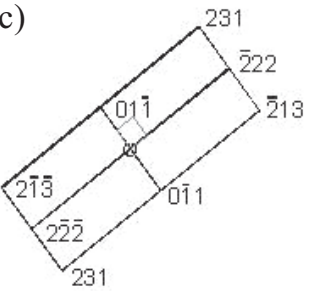

d)

$$
1000
$$

Fig. 5. Microstructure after spheroidization at $700^{\circ} \mathrm{C}, t=100 \mathrm{~h}$. The Bagaryatski OR: a) bright-field image; b) diffraction pattern; c) diffraction pattern solution for ferrite, zone axis [211]; d) diffraction pattern solution for cementite, zone axis [001] 
During the spheroidization annealing the morphological changes of microstructure are occur. Irrespective of the speroidization annealing time $(50 \mathrm{~h}, 100 \mathrm{~h}, 400 \mathrm{~h})$ the diffraction analysis showed the existence both the Bagaryatski OR (Fig. 5) and the Pitsch OR (or near to it) (Fig. 6).

a)

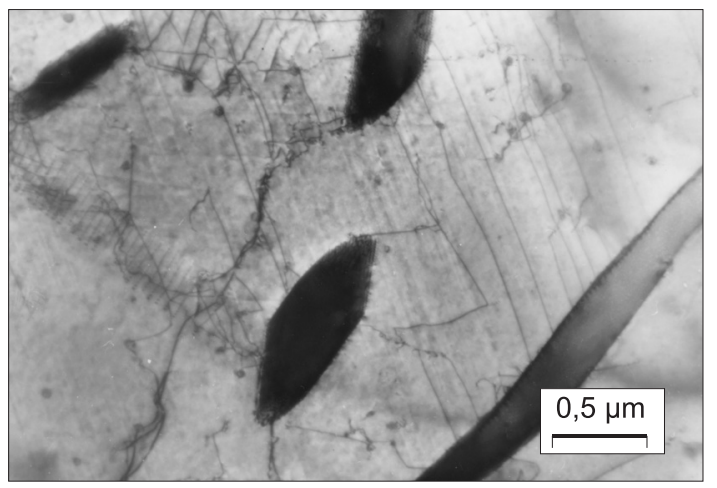

b)

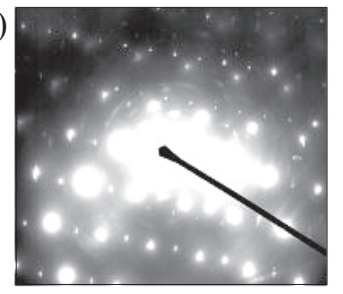

c)

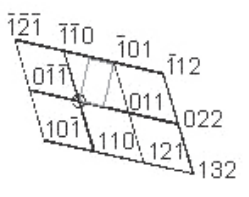

d)

$$
\text { (150) }
$$

Fig. 6. Microstructure after spheroidization at $700^{\circ} \mathrm{C}, t=100 \mathrm{~h}$. Orientation near to the Pitch OR: a) bright-field image; b) diffraction pattern; c) diffraction pattern solution for ferrite, zone axis [1 $1 \overline{1} 1]$; d) diffraction pattern solution for cementite, zone axis [3̄i1]

\section{SUMMARY}

A detailed microscopic analysis shows that during the spheroidization annealing the morphological changes are occur in a typical way i.e., areas of spheroidized cementite increase while lamellar fractions decrease successively (Figs. 1-2). The spheroidization process occurs not uniformly.

The diffraction analysis demonstrated the existence of the Bagaryatski OR and the Pitch OR both in the pearlite microstructure after eutectoid transformation and after each spheroidization annealing time (Figs. 3-6). The result achieved is a confirmation of Zhang and Kelly's data [30].

The obtained results of diffraction analysis indicate that the crystallographic orientation realationship between ferrite and cementite does not influence the stability of cementite revealing lamellar morphology. Despite that the Pitsch OR in the structure after pearlite transformation occurs rarer than Bagaryatski OR, its presence after each considered time of spheroidization annealing be stated.

The financial support from the Polish Ministry of Science and Higher Education (MNiSW) contract No. 11.11.110.405 is gratefully acknowledged. 


\section{REFERENCES}

[1] Bagaryacki Y.A.: Wierojatnyj mechanizm raspada martiensita. Dokłady Akademii Nauk SSSR, 73 (1950) 6, p. 1161-1164

[2] Baranow A.A.: O načalnych stadiach sferoidizacji cemientita w stali. Izwiestia Akademii Nauk SSSR. Metałły, (1969)3, p. 104-107

[3] Baranow A.A., Iwanow L.J.: O sfieroidizacji ewtektičeskowo karbida bystroriezuščej stali. Metałłofizyka, Naukowa Dumka Kijów, (1968) 25, p. 91-95

[4] Czarski A., Ryś J.: Morphology of Pearlite. Archives of Metallurgy, 32 (1987) 3, p. 453-463

[5] Dippenaar R.J., Honeycombe R.W.K.: The crystallography and nucleation of pearlite. Proc. R. Soc. London A. 333 (1973), 455-475

[6] Goodchild D.: Spheroidization of Pearlite in Cold Deformed Medium-Carbon Steel. Scandinavian Journal of Metallurgical, 1 (1972), p. 235-240

[7] Howell P.R., Honeycombe R.W.K.: Phase transformations in metals and alloys. Solid-Solid Phase Transformations. Editors: Aaronson H.I., Laughlin D.E., Sekerka R.F., Wayman C.M., Publication of the Metallurgical Society of AIME, New York, 1982, p. 399-422

[8] Isajčew I.W.: Orientacja cemientita w otpuščennoj uglierodistoj stali. Żurnal techničeskoj fizyki, 17 (1947) 7 , p. $835-838$

[9] Lupton D.F., Warrington D.H.: The zero-misfit analysis of pearlite nucleation in a eutectoid steel. (1972) 20, p. $1325-1333$

[10] Martin J.W., Doherty R.D.: Stability of Microstructure in Metallic Systems, Cambridge University Press 1976

[11] McLean M.: Microstructural instabilities in metallurgical systems-a review. Metal Science, (1978) 3, p. 113-122

[12] Mullins W.W.: Theory of Thermal Grooving. Journal of Applied Physics, 28 (1957), p. 333-339

[13] Nichols F.A., Mullins W.W.: Surface- (Interface-) and Volume-Diffusion Contributions to Morphological Changes Driven by Capillarity. Transactions of Metallurgical Society of AIME, 233 (1965), p. 1840-1848

[14] Nijhof G.H.: Einformung von Zementit in kaltverformtem Stahl mit lamellarem Perlit - Mechanismus und Kinetik. Härterei Techn. Mitt., 36 (1981) 5, p. 242-247

[15] Nijhof G.H.: Einfluss einer Kaltverformung auf die Einformung von Zementit in einem Stahl mit lamellarem Perlit. Härterei Techn. Mitt., 35 (1980) 2, p. 59-68

[16] Ohmori Y.: The Isothermal Decomposition of an Fe-C-B Austenite. Transactions of the Iron and Steel Institute of Japan, 11 (1971) 5, p. 339-348

[17] Pitsch $W$ : Der Orientierungszusammenhang zwischen Zementit und Ferrit im Perlit. Acta Metallurgica, 10 (1962), p. 79-80

[18] Ryś J., Wiencek K.: Koagulacja faz w stopach. Wyd. „Śląsk”, Katowice, 1979

[19] Samuel F.H., Hussein A.A.: A Crystallographic Study of Nucleation of Pearlite. Transactions of the Iron and Steel Instytute of Japan, (1983) 23, p. 65-70

[20] Samuel F.H.: A crystallographic study of pearlite growth in steels. Transactions of the Iron and Steel Instytute of Japan, (1983) 23, p. 403-408

[21] Sčastliwcew W.M., Jakowlewa I.t.: Elektronnomikroskopičeskoje isliedowanje strukturnych prewraščeni w perlitie. Fizika Mietałłow i Mietałłowiedienie, 1974, t. 38, nr 3, p. 571-579

[22] Shacleton D.N., Kelly P.M.: Orientation relationships in pearlite and the form of the pearlite/austenite interface. Journal of the Iron and Steel Institute, (1969) 207, p. 1253-1254

[23] Skowronek T., Czarski A., Satora K.: Kinetyka sferoidyzacji perlitu. Materiały XXX Szkoły Inżynierii Materiałowej, Kraków-Ustroń-Jaszowiec 2002, p. 205-209

[24] Skowronek T., Czarski A., Satora K.: Stabilność struktury płytkowej. XXXI Szkoła Inżynierii Materiałowej, Kraków- Krynica 7-10 X 2003, p. 137-142 
[25] Suchomlin G.D.: Elekronnomikrodyfrakcjonnoie isledowanie orientacjonnych sootnošeni fierrit-ciemientit w pierlitie. Fizyka Mietałłow i Mietałłowiedienije, 38 (1974) 4, p. 878-880

[26] Suchomlin G.D.: Kristałłogieometričeskie osobiennosti pierlita doewtiektoidnoj stali. Fizyka Mietałłow i Mietałłowiedienije, 42 (1976) 5, p. 965-970

[27] Tian Y.L., Kraft R.W.: Kinetics of Pearlite Spheroidization. Metallurgical Transaction A, 18A (1987), p. $1359-1369$

[28] Tian Y.L., Kraft R.W.: Mechanisms of Pearlite Spheroidization. Metallurgical Transaction A, 18A (1987), p. $1403-1414$

[29] Zhang M-X., Kelly P.M.: Accurate orientation relationships between ferrite and cementite in pearlite. Scripta Materialia, 37 (1997) 12, p. 2009-2015

[30] Zhang M-X., Kelly P.M.: Crystallography of spheroidite and tempered martensite. Acta Materialia, 46 (1998) 11, p. 4081-4091

Received

June 2007 